Department of Biochemistry, Punjab Agricultural University Ludhiana, India

KULDIP C. SHARMA, VEER KARAN SACHDEVA and SUDARSHAN SINGH

\title{
A comparative gross and lipid composition of Murrah breed of buffalo and cross-bred cow's milk during different lactation stages
}

\begin{abstract}
Summary
A comparative gross and lipid composition of the milk from buffalo and cross-bred cows, depicted that total lipid contents in buffalo milk are comparatively higher in early, mid lactation and almost two fold in late lactation than in cow. The total proteins, lactose and SNF (Solids-not-fat) contents are comparatively higher in buffalo than in cow's milk. The calcium, phosphorus and ash contents are comparatively higher in mid and late lactation than early lactation in both the species. Amongst lipids, triglycerides constitued the major fraction and phosphatidylcholine and sphingomyelin are the major phospholipids followed by phosphatidylserine and phosphatidylinositol in both the species and remained almost invariable during the whole of lactation period. The short chain fatty acids $\left(\mathrm{C}_{4}\right.$ to $\left.\mathrm{C}_{10}\right)$ are higher during mid than early and late lactation wheras total unsaturated fatty acids are lower during early and mid lactation than late lactation in both species
\end{abstract}

Key Words: milk ingredients, lipids, fatty acids, lactation, Murrah Buffalo, cross-bred cow

\section{Zuammenfassung}

Titel der Arbeit: Vergleich verschiedener Milchinhaltsstoffe bei indischen Murrah Büffeln und Kreuzungskühen wăhrend unterschiedlicher Laktationsstadien

Es wurden verschiedene Milchinhaltsstoffe bei jeweils neun laktierenden Murrah Buffelrindem und Kreuzungsrindern (Holstein Friesian x Red Dane x Sahiwal) verglichen. Die Untersuchungen beschränkten sich auf die wöchentliche Erfassung der Frischmilchproben innerhalb von drei Abschnitten des Laktationsverlaufes, nämlich bei Laktationsbeginn, -mitte und -ende. Es zeigte sich, daß der Gehalt an Gesamtlipiden in der Büffelmilch in allen drei Abschnitten hober lag als bei den Kreuzungskuhen. Das betraf auch den Gesamteiweißanteil und Laktosegehalt. In beiden Tiergruppen erreichten die Calzium-, Phosphor- und Ascheanteile in der Mitte und am Ende der Laktation höhere Werte als am Laktationsbeginn. Es werden die Werte für die einzelnen Lipid-, Phospholipidfraktionen sowie die Fettsäurezusammensetzung in der Milch dargestellt und Abweichungen in Abhăngigkeit von der Tiergruppe und dem Laktationsstadium diskutiert.

Schlusselwörter: Milchinhaltșstoffe, Lipide, Fettsăuren, Laktation, Murrah Buffel, Kreuzungskuhe

\section{Introduction}

Milk, the outcome of various biochemical activities in mammary secretory cell is composed of fat, protein, carbohydrates, enzymes, vitamins and various minerals. The composition as well as distribution pattern of enzymes in the milk is influenced by various factors, i.e., stage of lactation, lactation number, breed, feeding pattern, environmental and diseased condition of the udder (YADAV et al., 1991; NEERU and SINGH, 1995). The available information on the role of these factors in influencing the composition particularly the gross and detailed lipid composition is scanty both in cross-bred cows and buffaloes, the present investigation, therefore, has been undertaken on the comparative lipid composition of milk from cross-bred cows and murrah buffaloes during different lactation stages. 


\section{Materials and Methods}

Nine lactating HRS (Holstein Fresiane $x$ Red Dane $x$ Sahiwal) cross-bred cows and nine Murrah buffaloes, three each in their early, mid and late lactation stages, were selected from the herd maintained by the Department of Animal Science, Punjab Agricultural University, Ludhiana. Fresh milk samples were collected in duplicate from each cow and buffalo at weekly intervals.

\section{Determination of milk contents}

The total lipids were isolated and determined by the method of FOLCH et al. (1957) and total proteins by the method of PYNE (1951).

The lactose of the milk was estimated by the method of DUBOIS et al. (1956) and solids-not-fat (SNF) were determined by deducting the amount of total fat from total solids of milk A.O.A.C.(1984).

A known amount of the milk was taken in a pre-weighed silica dish and contents were dried by keeping it for $24 \mathrm{hrs}$. in oven at $100^{\circ} \mathrm{C}$. The charring was done and then kept in muffle furnace till the ash contents were free from carbon residue. Cooled in desicator and found its exact weight. The ash contents were expressed as $\mathrm{g} / \mathrm{dl}^{-1} \mathrm{milk}$.

A known amount of ash was dissolved in $100 \mathrm{ml}$ of $20 \% \mathrm{HCl}$ and this solution was used for the analysis of calcium by the method of A.O.A.C. (1980) and total phosphorus by the method of ROUSER et al. (1974).

The neutral and phospholipid components in total lipids were fractionated by thin layer chromatography on silica gel $G$ with petroleum ether : solvent ether : acetic acid $(80: 20: 2, \mathrm{v} / \mathrm{v})$ and chloroform : methanol : ammonia : water (115:45:3.75:3.75, v/v) solvent system respectively. The separated lipid components were detected with iodine vapours and identified using standard compounds chromatographed as markers. The neutral and phospholipid components were then scrapped from the chromatograms and eluted with diethyl ether : hexane $(1: 1, \mathrm{v} / \mathrm{v})$ and chloroform : methanol : acetic acid : water $(25: 15: 4: 2, \mathrm{v} / \mathrm{v})$ mixture respectively. The eluents of individual components were dried under nitrogen and contents of glycerides (VAN HANDEL and ZILVERSMIT, 1957), free fatty acids (LOWRY and TINSLEY, 1976), cholesterol and cholesterol esters (ZAK, 1957) and phospholipids (AMES, 1966) in their respective fractions were determined.

Methyl esters of fatty acids were prepared (CHRISTIE, 1972) and separated by gas liquid chromatography using a chromatograph (NUCON AIMIL, India, Model 5500) fitted with a flame ionisation detector. The gas liquid chromatographic separations were carried out on $1.8 \mathrm{~m} \times 3 \mathrm{~mm}$ stainless steel column packed with $20 \%(\mathrm{w} / \mathrm{w})$ diethylene glycol succinate on chromosorb-W (60-80 mesh) at $180^{\circ} \mathrm{C}$ with $\mathrm{N}_{2}$ as carrier gas $\left(1 \mathrm{~kg} / \mathrm{cm}^{2}\right.$ pressure). The flow rate of $\mathrm{N}_{2}$ was $20-30 \mathrm{ml} / \mathrm{min}$. Peak areas were determined by triangulation.

All values reported are mean of six observations \pm S.E. (three animals and two milk collections of each animals) separately for cow and buffalo. 


\section{Results and Discussion}

\section{Gross Composition}

The total lipids ( $\mathrm{g} / \mathrm{dl}^{-1}$ milk) constituted $3.5,4.5$ and $4.6 \%$ in cow and $6.3,6.4$ and $9.8 \%$ in buffalo during early, mid and late lactation separately. The concentrations of total lipids are almost similar in mid and late lactation than early lactation in cow, the corresponding values in buffalo are almost similar in early and mid lactation and are comparatively higher in late lactation. However, the total lipid contents in buffalo are comparatively higher and almost twofold in late lactation than in cow (Table 1). The concentrations of total proteins are slightly higher throughout the lactation period in cow than in buffalo. The concentration of lactose more or less is similar in mid and late lactation in cow (3.6\%) and buffalo (4.1\%) than early lactation. The S.N.F. and phosphorous contents are comparatively lower in cow than in buffalo throughout the lactation period whereas reverse is true for calcium contents (Table 1). The ash contents were almost similar in the early and mid lactation in cow than buffalo. However, the contents were almost similar in late lactation in both the species.

The composition of milk is largely affected by various factors i.e., lactation stage, lactation number, breed, feeding pattern and environmental factors (YADAV et al., 1991; NEERU and SINGH, 1995). The increase in total lipid contents may be due to the reason that activity of fatty acid synthesizing enzymes particularly acetyl CoA carboxylase which is a regulatory enzyme in the fatty acid synthesis might have slightly increased in late lactation than early and mid lactation. YADAV et al. (1991) reported the effect of stage of lactation on trends in fat, S.N.F. and total solids contents, in cross-bred dairy cattles and it was revealed that fat and total solids were higher in winter calvers during, 1st and 10 month of lactation, in summer calvers, during 6 th, 7 th and 8 th month of lactation.

The results depict that the SNF contents remain almost unchanged throughout the lactation period. The protein contents of both cow and buffalo milk increase towards the end of lactation. The maximum concentration of lactose is observed during early lactation in both the species. SHARMA et al. (1996) reported that lactose concentration varied from 2.7 to $4.8 \%$ in cow and remained invariable from 1 st week to fifth week and slight decrease was observed during the last two weeks in the summer. The ash, calcium and phosphorus contents of both cow and buffalo milk show an increasing trend with the progress of lactation stage (Table 1). Our results are in good agreement to those of MALHAPATI and BHATT (1988). These workers observed that ash, calcium and phosphorus contents increased towards the end of lactation.

\section{Lipid Composition}

The lipids of both cow and buffalo milk were constituted mainly of neutral and phospholipids (Table 2). The total neutral lipids were almost similar in cow and buffalo and the total phospholipids were lower in cow than in buffalo throughout the lactation period. Amongst the neutral lipids (Table 2), the triglycerides (TG) are the major neutral lipid fraction, which remain almost unchanged during all the stages of lactation followed by diglycerides (DG), monoglycerides (MG), total cholesterol, (CL) 
Table 1

Gross composition of Murrah buffalo and cross-bred cow's milk during different lactation stages (Milchinhaltsstoffe von Büffel- und Kuhmilch aus unterschiedlichen Laktationsabschnitten)

\begin{tabular}{|c|c|c|c|c|c|c|}
\hline \multicolumn{9}{|c|}{ Lactation Stages } \\
\hline \multicolumn{2}{|c|}{ Cow } & \multicolumn{2}{c|}{ Buffalo } \\
\hline Days after calving & $\begin{array}{c}\text { Early } \\
45\end{array}$ & $\begin{array}{c}\text { Mid } \\
125\end{array}$ & $\begin{array}{c}\text { Late } \\
280\end{array}$ & $\begin{array}{c}\text { Early } \\
45\end{array}$ & $\begin{array}{c}\text { Late } \\
280\end{array}$ \\
& & & & & \\
125 \\
\hline Components g/dl
\end{tabular}

Figure are mean of six observations \pm S.E., three animals and two milk collections of each animals

Table 2

Neutral lipid composition of Murrah buffalo and cross-bred cow's milk during different lactation stages (Lipidfraktionen in Büffel- und Kuhmilch in unterschiedlichen Laktationsabschnitten)

\begin{tabular}{|c|c|c|c|c|c|c|}
\hline \multicolumn{7}{|c|}{ Lactation Stages } \\
\hline \multicolumn{4}{|c|}{ Cow } & \multicolumn{3}{|c|}{ Buffalo } \\
\hline Days after calving & $\begin{array}{c}\text { Early } \\
45 \\
\end{array}$ & $\begin{array}{l}\text { Mid } \\
125 \\
\end{array}$ & $\begin{array}{l}\text { Late } \\
280 \\
\end{array}$ & $\begin{array}{c}\text { Early } \\
45 \\
\end{array}$ & $\begin{array}{c}\text { Mid } \\
125 \\
\end{array}$ & $\begin{array}{l}\text { Late } \\
280 \\
\end{array}$ \\
\hline $\begin{array}{l}\text { Components (\% of } \\
\text { total lipids) }\end{array}$ & & & & & & \\
\hline Total neutral lipids & $98.5 \pm 0.20$ & $97.8 \pm 0.14$ & $98.5 \pm 0.16$ & $98.4 \pm 0.25$ & $98.5 \pm 0.07$ & $98.4 \pm 0.24$ \\
\hline Trigylcerides HMW & $52.4 \pm 0.13$ & $51.7 \pm 0.23$ & $53.1 \pm 0.16$ & $52.2 \pm 0.22$ & $52.3 \pm 0.16$ & $51.5 \pm 0.19$ \\
\hline Triglycerides LMW & $42.3 \pm 0.08$ & $42.3 \pm 0.29$ & $41.1 \pm 0.07$ & $41.5 \pm 0.15$ & $41.7 \pm 0.20$ & $41.6 \pm 0.07$ \\
\hline Daglycerides & $0.84 \pm 0.02$ & $0.89 \pm 0.01$ & $1.00 \pm 0.002$ & $1.6 \pm 0.03$ & $1.6 \pm 0.05$ & $1.9 \pm 0.01$ \\
\hline Monoglycerides & $0.66 \pm 0.01$ & $0.54 \pm 0.01$ & $0.64 \pm 0.02$ & $0.64 \pm 0.01$ & $0.69 \pm 0.02$ & $0.66 \pm 0.03$ \\
\hline Total cholesterol & $1.7 \pm 0.01$ & $1.6 \pm 0.04$ & $1.80 \pm 0.02$ & $1.8 \pm 0.01$ & $1.6 \pm 0.07$ & $1.8 \pm 0.01$ \\
\hline Free fatty acids & $0.54 \pm 0.01$ & $0.71 \pm 0.02$ & $0.81 \pm 0.01$ & $0.58 \pm 0.01$ & $0.65 \pm 0.02$ & $0.84 \pm 0.07$ \\
\hline
\end{tabular}

Figure are mean of six observations \pm S.E., three animals and two milk collections of each animals 
Table 3

Phospholipid composition of Murrah buffalo and cross-bred cow's milk duimg different lactation stages (Phospholipidfraktionen in Buffel- und Kuhmilch in unterschiedlichen Laktationsabschnitten)

\begin{tabular}{|c|c|c|c|c|c|c|}
\hline \multicolumn{7}{|c|}{ Lactation Stages } \\
\hline \multicolumn{4}{|c|}{ Cow } & \multicolumn{3}{|c|}{ Buffalo } \\
\hline Days after calving & $\begin{array}{c}\text { Early } \\
45\end{array}$ & $\begin{array}{l}\text { Mid } \\
125\end{array}$ & $\begin{array}{l}\text { Late } \\
280\end{array}$ & $\begin{array}{c}\text { Early } \\
45\end{array}$ & $\begin{array}{l}\text { Mid } \\
125\end{array}$ & $\begin{array}{l}\text { Late } \\
280\end{array}$ \\
\hline $\begin{array}{l}\text { Components } \\
\text { (\% of total lipids) }\end{array}$ & & & & & & \\
\hline Total phospholipids & $0.92 \pm 0.008$ & $1.02 \pm 0.028$ & $1.2 \pm 0.01$ & $1.13 \pm 0.005$ & $1.21 \pm 0.205$ & $1.33 \pm 0.007$ \\
\hline Phosphatidyl ethanolamine & $0.28 \pm 0.005$ & $0.23 \pm 0.009$ & $0.38 \pm 0.007$ & $0.31 \pm 0.002$ & $0.30 \pm 0.008$ & $0.26 \pm 0.008$ \\
\hline Phosphatidyl choline & $0.21 \pm 0.009$ & $0.31 \pm 0.009$ & $0.23 \pm 0.004$ & $0.25 \pm 0.003$ & $0.27 \pm 0.008$ & $0.37 \pm 0.004$ \\
\hline Sphingomyelin & $0.25 \pm 0.003$ & $0.27 \pm 0.005$ & $0.36 \pm 0.004$ & $0.36 \pm 0.002$ & $0.39 \pm 0.005$ & $0.41 \pm 0.004$ \\
\hline Phosphatidyl serine & $0.17 \pm 0.002$ & $0.14 \pm 0.003$ & $0.12 \pm 0.004$ & $0.21 \pm 0.002$ & $0.23 \pm .003$ & $0.21 \pm 0.009$ \\
\hline Phosphalidyl inositol & $0.01 \pm 0.001$ & $0.10 \pm 0.004$ & $0.10 \pm 0.004$ & $0.01 \pm 0.001$ & $0.03 \pm 0.01$ & $0.07 \pm 0.002$ \\
\hline
\end{tabular}


Table 4

Fatty acid composition of Murrah buffalo and cross-bred cow's milk fat during different lactation stages (Fettsäurefraktionen in Büffel- und Kuhmilch in unterschiedlichen Laktationsabschnitten)

\begin{tabular}{|c|c|c|c|c|c|c|}
\hline \multicolumn{7}{|c|}{ Lactation Stages } \\
\hline \multicolumn{4}{|c|}{ Cow } & \multicolumn{3}{|c|}{ Buffalo } \\
\hline Days after calving & $\begin{array}{c}\text { Early } \\
45\end{array}$ & $\begin{array}{l}\text { Mid } \\
125\end{array}$ & $\begin{array}{l}\text { Late } \\
280\end{array}$ & $\begin{array}{c}\text { Early } \\
45\end{array}$ & $\begin{array}{l}\text { Mid } \\
125 \\
\end{array}$ & $\begin{array}{l}\text { Late } \\
280\end{array}$ \\
\hline $\begin{array}{l}\text { Components (Fatty } \\
\text { acids per cent of total } \\
\text { identifiable fatty acid) }\end{array}$ & & & & & & \\
\hline $\mathrm{C} 4: 0$ & $10.0 \pm 0.99$ & $9.0 \pm 0.72$ & $6.2 \pm 0.59$ & $5.7 \pm 0.78$ & $5.2 \pm 0.89$ & $4.1 \pm 0.96$ \\
\hline C6:0 & $4.1 \pm 0.30$ & $3.8 \pm 0.82$ & $3.4 \pm 0.96$ & $2.8 \pm 0.81$ & $3.7 \pm 0.46$ & $3.0 \pm 0.68$ \\
\hline C8:0 & $2.6 \pm 0.40$ & $2.0 \pm 0.20$ & $1.9 \pm 0.18$ & $1.8 \pm 0.26$ & $2.7 \pm 0.42$ & $2.0 \pm 0.19$ \\
\hline $\mathrm{C} 10: 0$ & $4.9 \pm 0.17$ & $2.9 \pm 0.18$ & $3.2 \pm 0.73$ & $3.0 \pm 1.04$ & $3.7 \pm 0.80$ & $3.9 \pm 0.80$ \\
\hline $\mathrm{C} 10: 1$ & $0.2 \pm 0.05$ & $0.3 \pm 0.09$ & $0.6 \pm 0.11$ & $0.2 \pm 0.03$ & $0.2 \pm 0.06$ & $0.2 \pm 0.11$ \\
\hline $\mathrm{C} 12: 0$ & $3.8 \pm 1.00$ & $6.0 \pm 0.56$ & $6.4 \pm 1.32$ & $3.7 \pm 0.65$ & $4.2 \pm 0.69$ & $3.6 \pm 0.32$ \\
\hline $\mathrm{C} 14: 0$ & $14.5 \pm 1.17$ & $12.7 \pm 0.81$ & $13.4 \pm 0.85$ & $14.9 \pm 0.85$ & $11.3 \pm 1.21$ & $11.9 \pm 0.99$ \\
\hline $\mathrm{Cl6:0}$ & $28.9 \pm 0.67$ & $28.9 \pm 0.67$ & $25.7 \pm 0.31$ & $34.6 \pm 1.01$ & $35.2 \pm 0.98$ & $32.9 \pm 1.47$ \\
\hline $\mathrm{C} 16: 1$ & $1.8 \pm 0.32$ & $1.6 \pm 0.15$ & $2.2 \pm 0.44$ & $1.4 \pm 0.35$ & $1.4 \pm 0.44$ & $2.7 \pm 0.29$ \\
\hline $\mathrm{C} 18: 0$ & $7.3 \pm 0.69$ & $9.8 \pm 0.24$ & $10.6 \pm 0.92$ & $9.2 \pm 1.33$ & $10.7 \pm 1.14$ & $9.4 \pm 0.74$ \\
\hline $\mathrm{C} 18: 1$ & $21.0 \pm 1.01$ & $21.6 \pm 0.34$ & $23.8 \pm 0.47$ & $19.0 \pm 0.16$ & $20.2 \pm 0.72$ & $23.2 \pm 1.29$ \\
\hline $\begin{array}{c}\text { Total saturated fatty } \\
\text { acids }\end{array}$ & $76.1 \pm 0.91$ & $75.2 \pm 0.54$ & $71.8 \pm 0.84$ & $76.9 \pm 0.55$ & $76.6 \pm 0.32$ & $70.9 \pm 1.35$ \\
\hline $\begin{array}{c}\text { Total unsaturated fatty } \\
\text { acids }\end{array}$ & $23.9 \pm 0.91$ & $24.8 \pm 0.54$ & $28.2 \pm 0.84$ & $23.1 \pm 0.55$ & $23.4 \pm 0.32$ & $29.1 \pm 1.35$ \\
\hline
\end{tabular}

Figure are mean of six observations \pm S.E., three animals and two milk collections of each animals 
and free fatty acids (FFA). Our results depicted that total cholesterol contents are almost similar in both cow and buffalo, during all the stages of lactation. The isotopic studies indicate that both CL, Cholesterol esters (CE), minor components of milk fat originate from de novo synthesis within the mammary gland (KAUSHAL et al., 1984). The FFA contents are higher during late than early and mid lactation in both the species (Table 2).

These results are in good agreement to those as reported by BANERJEE et al. (1991). Our result depicted that the HMWTG contents of cow and buffalo milk are almost similar during early and mid lactation while HMWTG contents of cow are higher than buffalo milk during late lactation. Higher values of total cholesterol were reported in cow than buffalo milk by SHARMA et al. (1996).

The phospholipid composition of milk fat during different lactation stages (Table 3) revealed that Phosphatidylethanolamine (PE), Phosphatidylcholine (PC) and sphingomyle in (SPH) are the major phospholipid fractions followed by Phosphatidy1serine (PS) and Phosphatidylinositol (PI). The total phospholipid contents are higher during late than early and mid lactation in both the species. The PE contents of cow's milk are higher during late and lower during early and mid lactation as compared to buffalo milk. The PC contents are higher during mid lactation in cow and lower during early lactation in buffalo milk. The SPH and PS contents of milk are higher in buffalo than cow during all the stages of lactation. The PI contents are almost similar in both the species during all the stages of lactation. Our results are in good agreement to those as reported by BITMAN and WOOD (1990) which reported that $\mathrm{PE}, \mathrm{PC}$ and $\mathrm{SPH}$ are observed to be higher during late and lower during early lactation. However, PI contents remain almost unchanged throught the lactation period.

\section{Fatty acid composition of milk fat}

The fatty acid distribution in total lipids of cow and buffalo milk (Table 4) shows that both $\mathrm{C} 16: 0$ and $\mathrm{C} 18: 1$ are the major fatty acids followed by $\mathrm{C}_{14: 0}{ }^{\text {' }} \mathrm{C}_{4: 0}, \mathrm{C}_{18: 0}{ }^{\prime} \mathrm{C}_{12: 0}$ ' $\mathrm{C}_{6: 0}, \mathrm{C}_{10: 0}, \mathrm{C}_{8: 0}, \mathrm{C}_{16: 1}, \mathrm{C}_{18: 2}$ ' $\mathrm{C}_{14: 1}$ and $\mathrm{C}_{10: 1}$ respectively. The concentrations of $\mathrm{C}_{16: 0}$ are lower and that of $\mathrm{C}_{18: 0}$ higher during late than early and mid lactations in cow. However, reverse pattern is observed in buffalo milk (Table 4). The concentrations of $\mathrm{C}_{14: 0}$ are higher and that of $\mathrm{C}_{18: 0}$ at lower during early than mid and late lactation in both the species. The short chain fatty acids $\left(\mathrm{C}_{4: 0}\right.$ to $\left.\mathrm{C}_{10: 0}\right)$ of cow milk are higher during early than mid and late lactation. However, in buffalo milk the short chain fatty acids are higher during mid than early and late lactation. The total saturated fatty acids of cow's milk are higher during the early and mid than the late lactation. Whereas in buffalo milk total saturated fatty acids during, the early and mid lactation are almost similar and higher than late lactation. The total unsaturated fatty acids of cow and buffalo's milk fat are higher during late than early and mid lactations. Our results compare favourably to that of BANERJEE et al. (1991b).

\footnotetext{
References

AMES, B.N.:

Assay of inorganic phosphates. In "Methods in Enzymology". Eds. E.F. Neufeld and V.Gruisburg, Academic Press, New York, Vol. VIII (1966), 115-118
} 
ARUMUGHAN, C.; NARAYANAN, K.M.:

Trialcylglycerol composition of buffalo milk fat. J. Dairy Res. 49 (1982), 81-85

ASSOCIATION OF OFFICIAL ANALYTICAL CHEMISTS: Official methods of Analysis, 13th Ed. (1980) Arlington, VA.

ASSOCIATION OF OFFICIAL ANALYTICAL CHEMISTS: In official methods of analysis. S. Williams (Ed.) (1984). Arlington, U.S.A. PP. 281

BANERJEE, R.; BANDYOPADHYAY, C.; SUBRAHMANYAM, V.V.R.: Composition of cow's milk fat during transition fom colostrum to normal. Part I: changes in lipid constituents . Indian J. Dairy Sci., 44 (1991a) 1, $62-65$

BANERJEE R.; BANDYOPADHYAY, C.; SUBRAHMANYAM, V.V.R.: Composition of cow's milk fat during transition from colostrum to normal. Part II: changes in fatty acids and glycerides. Indian J. Dairy Sci, 44 (1991b) 1, 66-70

BITMAN, J.; WOOD, D.L.: Changes in milk fat phospholipids during lactation. J. Dairy Sci. 73 (1990), 1208-1216

CHRISTIE, W.W.: Preparation of methyl esters of fatty acids. In: Lipid Analysis, Pergamon Press, New York (1972) pp. 89

DUBOIS, M.; GILLES, K.A.; HAMILTON, J.A.; ROBERS, P.A.; SMITH, F.: Colorimetric methods for determination of sugars and related substances. Anal. Chem. 28 (1956), 350356

FOLCH, J.; LEES, M.; SOLANE-STANLEY, G.H.:

A simple method for the isolation and purification of total lipids from animal tissues. J. Biol. Chem. 226 (1957), 497-507

JAIN, D.K.; SHARMA, K.N.S.; BHATNAGAR, D.S.; SHARMA, R.C.:

Fat and S.N.F. concentration in cow's milk as affected by pubrity and stage of lactation. Indian J. Dairy Sci. 40 (1987), 111-118

KAUSHAL, J.R.; SINGH, A.; SHARMA, K.C.: Asian J. Dairy Res. 3 (1984), 117-120

LOWRY, R.R.; TINSLEY, I.J.: Rapid colorimetric determinations of free fatty acids. J. Am. Oil. Chem. Soc. 53 (1976), 470-472

MALHAPATI, S.S.; BHATT, G.S.: Comparison of some properties of milk from cross-bred cows. Indian J. Dairy Sci. 41 (1988), 171-173

NEERU, ; SINGH, M: Mammary gland development and milk compositional changes in hormonally induced lactating buffaloes. Indian J. Dairy Sci., 48 (1995) 3, 216-222

PYNE, G.T. : Casein heterogenocity and rennet coagulation. Chemistry and Industry. March (1951), 171-172

ROUSER, G.; KRITANEVSKY, G.; YAMAMOTO, A.: Lipid chromatographic analysis Vol. 3 (1974) New York, U.S.A. Marcel Dekker Inc. Ed. 713-716.

SHARMA, K.C.; VARINDRA, ; SINGH, S.: Day-to-day variations in total cholesterol and some other components of milk from cow and buffalo during summer. Indian J. Dairy Sci., 49 (1996), 472-476

VAN HANDEL, E.; ZILVERSMIT, D.B.: Micromethod for direct determination of serum triglycerides. J. Lab. Clin. Med. 50 (1957), 152-157

YADAV, S.B.S.; YADAV, A.S.; YADAV, M.S.: Seasonal fluctuations in milk composition at various stages of lactation in cross-breed dairy cattles. Indian J. Dairy Sci., 44 (1991), 33-36

ZAK, B.:

Simple rapid microtechnique for serum total cholesterol. Am. J. Clin. Path. 27 (1957), 583-588

Received: 1998-04-14

Accepted: $2000-02-21$

Authors address

Dr. KULDIP C. SHARMA, Senior Biochemist, Dr. VEER KARAN SACHDEVA,

Dr. SUDARSHAN SINGH

Punjab Agricultural University

Department of Biochemistry

Ludhiana - 141004

India 